Ann. Sci. forest., 1980, 37 (4), 279-289.

\title{
Variation in susceptibility of beech (Fagus spp) to beech scale (Cryptococcus fagisuga)
}

\author{
D. WAINHOUSE and R. DEEBLE * \\ Forestry Commission Research Station, Alice Holt Lodge, \\ Wrecelesham, Farnham, Surrey. GU10 4LH U. K.
}

\begin{abstract}
Summary
Data are presented showing clonal differences in severity of attack by Cryptococcus fagisuga on beech scions in three seed orchards in southern England. These differences may be due to genetically controlled resistance or to stock/scion incompatibility producing changes in the scion favourable for growth and development of $C$. fagisuga. It is concluded that differences are probably genetic in origin but that host response to attack and environmental factors probably interact to produce the complex pattern of attack seen in the forest.
\end{abstract}

\section{Introduction}

Infestation of beech trees (Fagus spp.) by the beech scale Cryptococcus fagisuga Lind. (C. fagi Baer.) is usually the first stage in the development of beech bark disease. Heavy infestations of this insect are frequently followed by infection of bark by the fungus Nectria coccinea (Pers. ex. Fr.) Fries in Europe (Parker, 1974) or N. coccinea var. foginata Lohman, Watson and Ayers, in North America (Lohman and Watson, 1943) which results in more or less extensive bark death (Ehrlich, 1934 ; Parker, 1974).

The importance of $C$. fagisuga in enhancing fungal attack is widely recognised (Ehrlich, 1934 ; Lonsdale, 1980) and Perrin (this volume) will discuss more fully the role of the two organisms in the disease complex.

In the forest there is usually considerable variation between trees in the degree of infestation by $C$. fagisuga. Heavily infested and uninfested or only lightly infested trees often occur adjacent to each other (Boodle and Dallimore, 1911 ; Thomsen et al., 1949 ; Kuthe and Kramer, 1961 ; Shigo, 1964). In many cases such differences persist for many years and are unlikely to have resulted from escape from attack as the estimated mean distance of larval dispersal from a heavily infested tree in the forest is about $10 \mathrm{~m}$ in windspeeds of $<1 \mathrm{~ms}^{-1}$ (Wainhouse, in press).

Such differences in degree of attack by $C$. fagisuga may reflect the influence of environmental factors or the existence of genetically resistant individuals in the population. There have been several reports of varietal differences in susceptibility to attack.

* c/o School of Biological Sciences, South Building, University of Bath, Claverton Down, Avon, U. K. 
Newstead (1901) suggested that weeping beech ( $F$. sylvatica var pendula) was more resistant to scale than the ordinary form and Carpenter (1903) observed that a weeping beech scion was unattacked while the ordinary beech stock on to which it was grafted was heavily attacked. Gillanders (1908) and Forestry Commission (1926) reported that in Britain, copper beech ( $F$. sylvatica var purpurea) is less attacked than ordinary beech and this is supported by Schenk's (1924) observations on a copper beech scion, analogous to those of Carpenter (loc. cit.). These observations have not been subsequently confirmed and indeed Green (1915) suggested that copper beech was more susceptible than normal beech.

Camp (1950) recognised three basic types of American beech (Fagus grandifolia Ehrh.) grey, red and white. Red beech appeared to be most susceptible (Camp, 1951) and this was attributed to the rough character of the bark, the crevices providing shelter for the scales. In addition grey beech seemed to be more resistant to the spread of Nectria canker.

In 1978 we examined the distribution of $C$. fagisuga attack on clonal trees in seed orchards in an attempt to establish whether there were differences in attack between trees that could be ascribed to the genetic origin of the trees.

\section{The seed orchards}

Beech seed orchards comprising clones of «plus » parent trees were established by the Forestry Commission Genetics Department as part of a tree breeding programme. The "plus » trees originated from various woods and private estates in Great Britain (Table 1), and represented the top 10 per cent for height growth, diameter growth, stem straightness and general habit of growth. The clones were grafted onto non-clonal root stocks and planted in the orchards on a rectangular polycross design (Giertych, 1975). Annual manurial treatments for each plant for the first seven years consisted of $28-56 \mathrm{~g}$ of nitrochalk top dressing followed by an application of grass mulch and hop waste. Plants which failed during the first 10 years were replaced.

TABLE 1

Origin of clones planted in seed orchards at Alice Holt and Hemsted

Origine des clones plantés dans un verger à graine à Alice Holt et Hemsted

\begin{tabular}{|c|c|}
\hline \multicolumn{2}{|c|}{ Clones } \\
\hline No. & Origin \\
\hline $\begin{array}{l}1 \text { and } 3-14 \\
20 \\
30 \text { and } 31 \\
60-69 \\
105 \text { and } 106 \\
270 \\
441 \\
460\end{array}$ & $\begin{array}{l}\text { Kingscote, Gloucestershire } \\
\text { Popeswood, Gloucestershire } \\
\text { Cirencester, Gloucestershire } \\
\text { Slindon, Sussex } \\
\text { Amberley, Gloucestershire } \\
\text { Wells, Roxburghshire } \\
\text { Yester, East Lothian } \\
\text { Dawyck, Peebles }\end{array}$ \\
\hline
\end{tabular}


Three orchards were examined, one near the Research Station at Alice Holt in Hampshire and two at Hemsted in Kent. The Alice Holt orchard contained thirteen clones from trees which had been planted in 1813 on the Kingscote estate, Gloucestershire. It was planted in 1960 with the trees 4-5 m apart and ten or twenty replicates of each clone. Hemsted orchard (1) contained ten clones from parent trees planted about 1760 on the Slindon estate, Sussex. It was planted in 1956 with the trees $6 \mathrm{~m}$ apart and twenty replicates of each clone. Hemsted (2) contained clones from parent trees in various woods and estates, namely, Popeswood, Cirencester, Slindon, Amberley, Wells, Yester and Dawyck planted between about 1700 and 1820 . The orchard was planted in 1957 with the trees $6 \mathrm{~m}$ apart and eighteen replicates of each clone. The arrangement of clones in the Alice Holt orchard (fig. 1) is shown before thinning in 1978. The Hemsted orchards were thinned in 1977 and the position of clones after thinning is shown in figures 2-3.

\section{Abundance of Cryptococcus fagisuga}

In September 1978 the bole of each scion in the three orchards was assessed visually and the abundance of $C$. fagisuga scored on a rank of 1-3 as follows : 1 . From zero to a few small colonies scattered over the bark surface, no large colonies present. 2. Moderate number of small colonies with some larger colonies present. 3 . Many small and large colonies present over much of the bark. For each orchard, the differences between clones in the abundance of $C$. fagisuga were analysed by the Kruskal-Wallis one-way analysis of variance by ranks (Siegel, 1956). All three orchards showed differences ( $P<0.01-0.001$ ) between clones in the abundance of $C$. fagisuga (fig. 1-3).

At Alice Holt orchard, clone 11 was most affected with 10,13 and 14 also moderately attacked ; clones 1, 5 and 7 were least attacked. At Hemsted (1) clones 62, 66 and 68 and at Hemsted (2), 31 and 270 were most affected and the others were relatively little attacked.

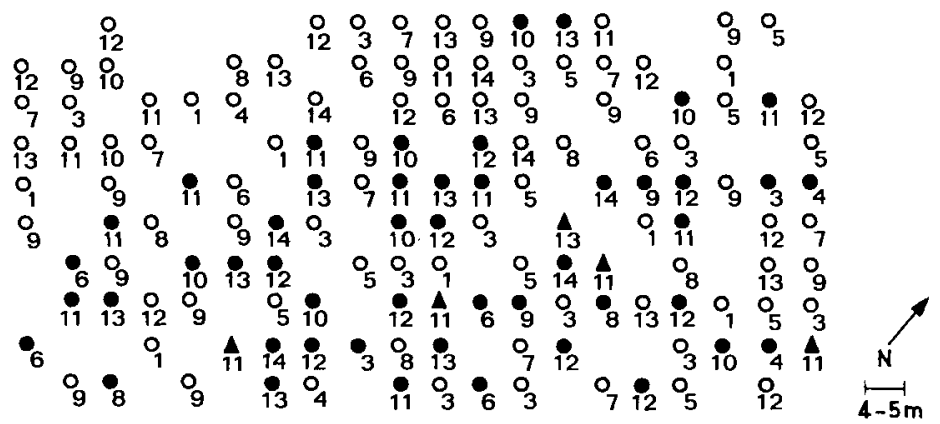

FIG. 1. - Alice Holf seed orchord showing distribution of clones. Abundance of Cryptococcus fagisuga, 1,0 2,॰ 3,A.

Verger à graines d'Alice Holt, montrant la distribution des clones. Abondance de Cryptococcus fagisuga, 1,0 2,॰ 3,4. 


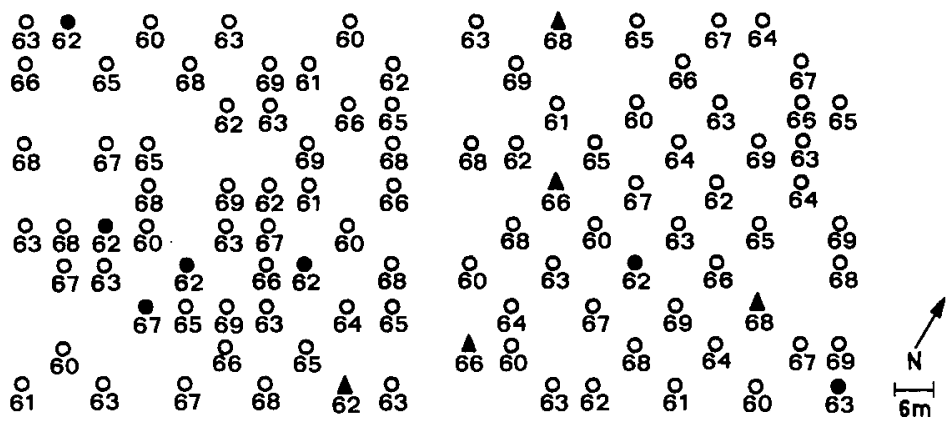

FIG. 2. - Hemsted seed orchard (1) showing distribution of clones. Abundance of Cryptococeus fagisuga, 1,0 2, 3,4.

Verger à graines de Hemsted (1) montrani la distribution des clones. Abondance de Cryptococcus fagisuga 1.0 2.e 3.A.

69

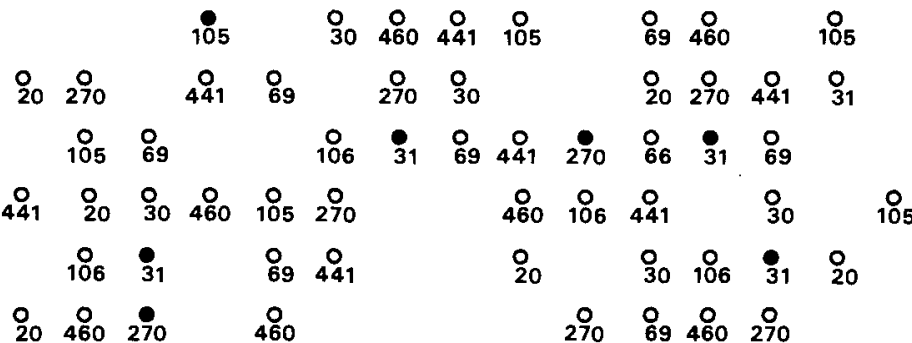

105

270

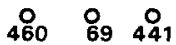

잉

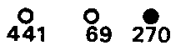

106

인

31 270

ㅇำ

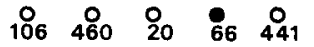

잉

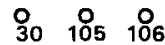

$\stackrel{\circ}{105} \stackrel{20}{20}$

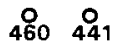

106

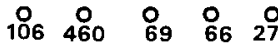

오

우웅

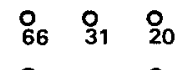

$\begin{array}{ll}0 & 0 \\ 441 & \circ 6\end{array}$

$\stackrel{\circ}{105}$

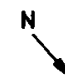

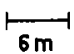

FIG. 3. - Hemsfed seed orchard (2) showing distribution of clones.

Abundance of Cryptococcus fagisuga, 1,0 2, 3,4 -.- beech hedge.

Verger à graines d'Hemsted (2) montrant la distribution des clones.

Abondance de Cryptococcus fagisuga, 1,0 2, 3,4 -.. haie de hêtres.

\section{Relationship between abundance of Cryptococcus fagisuga and tree diameter}

Within the orchards there was considerable variation in tree diameter resulting partly from replacement of failed trees. The diameter of each scion was measured 
about $150 \mathrm{~mm}$ above the point of grafting and trees placed in one of three diameter classes, $<50 \mathrm{~mm}, 50-150 \mathrm{~mm}$ and $>150 \mathrm{~mm}$. For each clone the mean score of $C$. fagisuga abundance for each diameter class was determined (Table 2).

\section{TABLE 2}

Mean score for abundance of Cryplococcus fagisuga for each clone in relation to scion diamefer class. * Before thinning in 1978

Note moyenne de l'abondance de C. fagisuga pour chaque clone en relation avec la classe de diamètre du scion. * Avant éclaircie en 1978

Clone Notrees $\quad<50 \mathrm{~mm} \quad \begin{gathered}\text { Diameter Class } \\ 50-150 \mathrm{~mm}\end{gathered}>150 \mathrm{~mm} \quad$ Mean $\begin{gathered}\text { per cent trees } \\ >150 \mathrm{~mm}\end{gathered}$

Alice Holf*

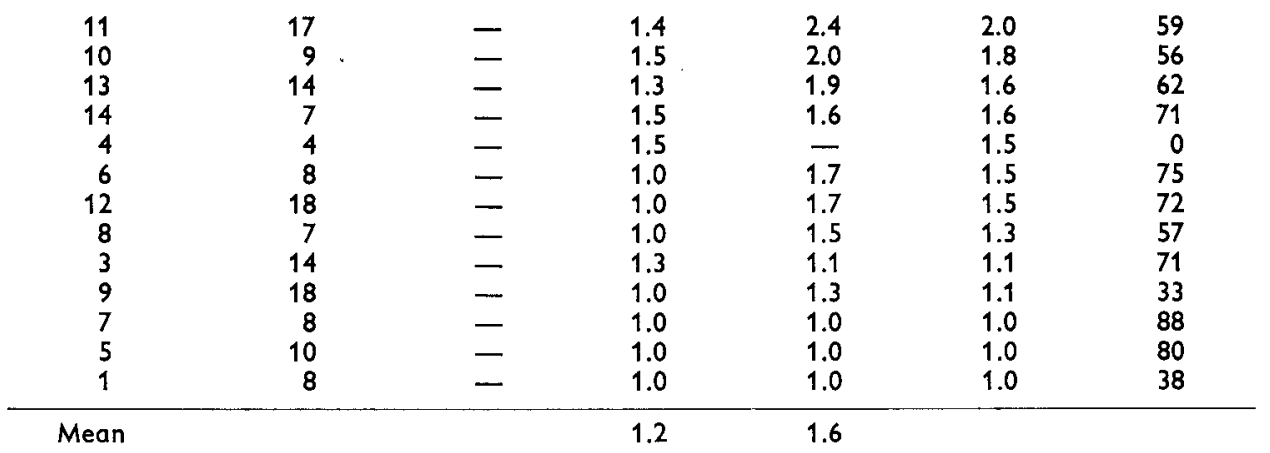

Hemsted 1

\begin{tabular}{|c|c|c|c|c|c|c|}
\hline $\begin{array}{l}62 \\
66 \\
68 \\
67 \\
63 \\
60 \\
61 \\
64 \\
65 \\
69\end{array}$ & $\begin{array}{r}12 \\
10 \\
13 \\
10 \\
16 \\
10 \\
5 \\
6 \\
10 \\
9\end{array}$ & $\begin{array}{l}1.0 \\
- \\
- \\
- \\
- \\
-\end{array}$ & $\begin{array}{l}1.0 \\
1.0 \\
1.0 \\
1.0 \\
1.0 \\
1.0 \\
1.0 \\
1.0 \\
-\end{array}$ & $\begin{array}{l}1.6 \\
1.6 \\
1.3 \\
1.1 \\
1.1 \\
1.0 \\
1.0 \\
1.0 \\
1.0 \\
1.0\end{array}$ & $\begin{array}{l}1.6 \\
1.4 \\
1.3 \\
1.1 \\
1.1 \\
1.0 \\
1.0 \\
1.0 \\
1.0 \\
1.0\end{array}$ & $\begin{array}{r}92 \\
70 \\
100 \\
90 \\
94 \\
90 \\
40 \\
67 \\
80 \\
100\end{array}$ \\
\hline & & 1.0 & 1.0 & 1.2 & & \\
\hline
\end{tabular}

Hemsted 2

\begin{tabular}{rrrrrrr}
31 & 10 & 1,0 & 1.7 & 2.0 & 1.6 & 20 \\
270 & 13 & 1.0 & 1.5 & 1.3 & 1.3 & 46 \\
66 & 8 & 1.0 & 1.0 & 2.0 & 1.1 & 13 \\
105 & 11 & 1.0 & 1.2 & 1.0 & 1.1 & 9 \\
20 & 10 & 1.0 & - & 1.0 & 1.0 & 40 \\
30 & 8 & 1.0 & 1.0 & 1.0 & 1.0 & 63 \\
69 & 15 & 1.0 & 1.0 & 1.0 & 1.0 & 47 \\
106 & 10 & 1.0 & 1.0 & 1.0 & 1.0 & 40 \\
441 & 13 & 1.0 & 1.0 & 1.0 & 1.0 & 46 \\
460 & 12 & 1.0 & 1.0 & 1.0 & 1.0 & 33 \\
\hline Mean & & 1.0 & 1.2 & 1.1 & &
\end{tabular}


At Alice Holt and Hemsted (1) the highest mean score of $C$. fagisuga occurred on the largest trees. At Hemsted (2) trees in diameter classes $50-150 \mathrm{~mm}$ and $>150 \mathrm{~mm}$ were both more heavily attacked than the smaller trees $(<50 \mathrm{~mm})$. The percentage of large trees $(>150 \mathrm{~mm}$ ) in each clone was determined and comparing the last two columns in Table 2 shows that the differences between clones in abundance of $C$. fagisuga do not result from differences in the proportion of large trees.

\section{Relationship between abundance of Cryptococcus fagisuga and graft type}

Some trees were deformed at the point of grafting and this may indicate incompatibility between stock and scion which could have influenced scale population buildup on the scion. We recorded apparent variation in compatibility by recognising the following graft types ; 1 . Stock and scion of the same diameter at the point of grafting with no distortion of the stem ; 2 . Stock diameter greater than scion; 3 . Scion diameter greater than stock; 4 . Both stock and scion enlarged or swollen in the region of the graft. The assessment of graft type at Alice Holt was done only on trees remaining after thinning in 1978. The mean score of $C$. fagisuga infestation for each graft type was determined for each clone (Table 3).

Graft type 3 had the highest mean score at Alice Holt and Hemsted (1) but this was only based on three individuals. The two highest scoring graft types at Alice Holt, Hemsted (1) and Hemsted (2) were 2 and 3,1 and 3 and 2 and 4 respectively. For each orchard, their percentage in each clone was determined (Table 3 ). The clonal differences in $C$. fagisuga abundance were not related to differences in the proportion of these graft types within each clone.

\section{Discussion}

Results from this study show that there are differences in abundance of $C$. fagisuga befween clones of beech trees planted in seed orchards in southern England. These differences may represent genetically controlled resistance or may have been induced by grafting. The scale insects were most abundant on the larger trees as has been observed in some forests (Ehrlich, 1934 ; Barter, 1947 ; Wainhouse and Deeble, unpublished data). This effect seems to be quite separate from the clonal differences observed but as no records had been kept on replacement of failed trees in the orchards, larger trees may be either older or faster growing than smaller ones.

The process of grafting may produce physiological changes in the scion, for example, the disruption of phloem transport leading to accumulation of nutrients in the scion (Dickson and Samuels, 1956 ; Rogers and Beakbane, 1957), possibly rendering some clones more susceptible to $C$. fagisuga attack. In grafted trees uneven growth at the union with swelling and overgrowth is often regarded as a sign of incompatibility (Argles, 1937). In our orchards there was no consistent association between scale abundance and the external form of the graft union, suggesting that the process of grafting had not affected susceptibility to attack. However, incompatibility does not 
TABLE 3

Mean score for abundance of Cryptococcus fagisuga for each clone in relation to graft type. No. of trees in brackets. * After thinning in 1978

Note moyenne d'abondance de C. fagisuga pour chaque clone en relation avec le type de greffe. No des arbres entre parenthèses. * Après éclaircie en 1978

\begin{tabular}{|c|c|c|c|c|c|c|}
\hline Clone & No.trees & 1 & $\begin{array}{l}\text { Graft type } \\
2\end{array}$ & 4 & Mean & $\begin{array}{c}\text { per cent graft type } \\
2+3\end{array}$ \\
\hline
\end{tabular}

alice Holt *

\begin{tabular}{|c|c|c|c|c|c|c|c|}
\hline $\begin{array}{r}11 \\
13 \\
10 \\
6 \\
12 \\
14 \\
4 \\
8 \\
3 \\
7 \\
1 \\
5 \\
9\end{array}$ & $\begin{array}{r}13 \\
9 \\
7 \\
7 \\
9 \\
3 \\
3 \\
4 \\
5 \\
6 \\
7 \\
9 \\
11\end{array}$ & $\begin{array}{c}1.5(6) \\
2.0(3) \\
1.7(3) \\
1.0(1) \\
1.8(4) \\
1.5(2) \\
1.3(3) \\
1.0(2) \\
1.0(1) \\
1.0(6) \\
1.0(6)\end{array}$ & $\begin{array}{l}2.5(4) \\
1.7(3) \\
1.8(4) \\
2.0(4) \\
1.0(2) \\
1.0(1) \\
1.3(3) \\
1.0(1) \\
1.0(3) \\
1.0(4) \\
1.0(1)\end{array}$ & $\begin{array}{c}2.0(1) \\
- \\
- \\
- \\
- \\
- \\
- \\
- \\
-\end{array}$ & $\begin{array}{c}2.0(3) \\
1.5(2) \\
- \\
1.0(2) \\
1.3(3) \\
- \\
- \\
1.3(3) \\
1.0(3) \\
1.0(2) \\
1.0(3) \\
1.0(4)\end{array}$ & $\begin{array}{l}1.9 \\
1.8 \\
1.7 \\
1.6 \\
1.4 \\
1.3 \\
1.3 \\
1.3 \\
1.2 \\
1.0 \\
1.0 \\
1.0 \\
1.0\end{array}$ & $\begin{array}{r}31 \\
44 \\
57 \\
57 \\
22 \\
33 \\
100 \\
25 \\
0 \\
50 \\
57 \\
0 \\
9\end{array}$ \\
\hline Mean & & 1.4 & 1.5 & 2.0 & 1.2 & & $\begin{array}{c}\text { ent gr } \\
1+\end{array}$ \\
\hline
\end{tabular}

Hemsted 1

\begin{tabular}{|c|c|c|c|c|c|c|c|}
\hline $\begin{array}{l}62 \\
66 \\
68 \\
67 \\
63 \\
60 \\
61 \\
64 \\
65 \\
69\end{array}$ & $\begin{array}{r}12 \\
10 \\
13 \\
10 \\
16 \\
10 \\
5 \\
6 \\
10 \\
9\end{array}$ & $\begin{array}{l}1.5(8) \\
1.5(8) \\
1.3(12) \\
1.2(6) \\
1.0(8) \\
1.0(8) \\
1.0(4) \\
1.0(2) \\
1.0(5) \\
1.0(6)\end{array}$ & $\begin{array}{c}-\overline{1} \\
1.0(2) \\
1.0(1) \\
1.0(1) \\
1.3(4) \\
1.0(1) \\
1.0(1) \\
1.0(1) \\
1.0(2)\end{array}$ & $\begin{array}{c}3.0(1) \\
- \\
- \\
- \\
- \\
- \\
1.0(1) \\
-\end{array}$ & $\begin{array}{c}1.3(3) \\
- \\
1.0(3) \\
1.0(4) \\
1.0(1) \\
1.0(4) \\
1.0(3) \\
1.0(1)\end{array}$ & $\begin{array}{l}1.6 \\
1.4 \\
1.3 \\
1.1 \\
1.1 \\
1.0 \\
1.0 \\
1.0 \\
1.0 \\
1.0\end{array}$ & $\begin{array}{l}75 \\
80 \\
92 \\
60 \\
50 \\
80 \\
80 \\
33 \\
60 \\
67\end{array}$ \\
\hline Mean & & 1.2 & 1.1 & 2.0 & 1.1 & & 11 \\
\hline
\end{tabular}

Hemsted 2

\begin{tabular}{|c|c|c|c|c|c|c|c|}
\hline $\begin{array}{r}31 \\
270 \\
66 \\
105 \\
20 \\
30 \\
69 \\
106 \\
441 \\
460\end{array}$ & $\begin{array}{r}10 \\
13 \\
8 \\
11 \\
10 \\
8 \\
15 \\
10 \\
13 \\
12\end{array}$ & $\begin{array}{l}1.0(2) \\
1.0(2) \\
1.0(2) \\
1.0(3) \\
1.0(5) \\
1.0(7) \\
1.0(3) \\
1.0(2) \\
1.0(7) \\
1.0(10)\end{array}$ & $\begin{array}{l}2.3(4) \\
1.3(4) \\
1.0(4) \\
1.3(4) \\
1.0(4) \\
1.0(1) \\
1.0(10) \\
1.0(2) \\
1.0(4) \\
1.0(1)\end{array}$ & $\begin{array}{c}1.0(1) \\
- \\
- \\
- \\
- \\
- \\
-\end{array}$ & $\begin{array}{l}1.3(4) \\
1.5(6) \\
1.5(2) \\
1.0(4) \\
1.0(1) \\
-\overline{1} \\
1.0(2) \\
1.0(6) \\
1.0(2) \\
1.0(1)\end{array}$ & $\begin{array}{l}1.6 \\
1.3 \\
1.1 \\
1.1 \\
1.0 \\
1.0 \\
1.0 \\
1.0 \\
1.0 \\
1.0\end{array}$ & $\begin{array}{l}80 \\
77 \\
75 \\
73 \\
50 \\
13 \\
80 \\
80 \\
46 \\
17\end{array}$ \\
\hline Mean & & 1.0 & 1.2 & 1.0 & 1.2 & & \\
\hline
\end{tabular}




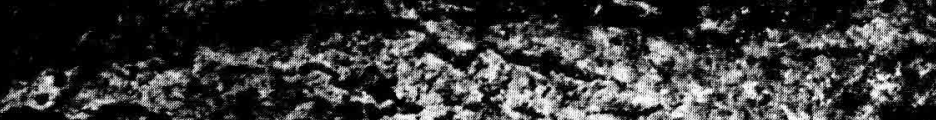

tita

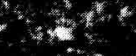

a

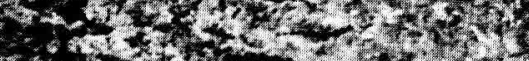

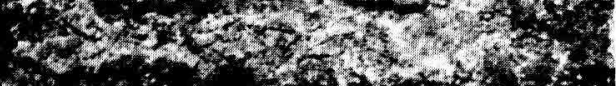
(in.

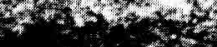
. 12

$\stackrel{\infty}{\sigma}$ อ

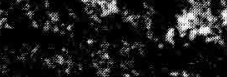

ह 인

อ

6. $+x^{3}+\mathrm{C}^{2}$

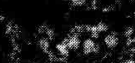

$x+4, y+3 x+3$

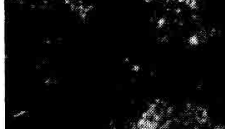
int. $3^{2}$ $4=$ $x^{2}+2$

4

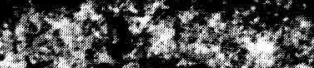

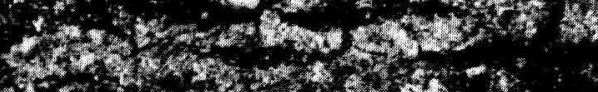

¿

¿

욜

$-4(x)+2$

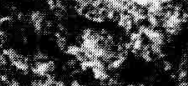

$3 x^{2}$

3

cas:

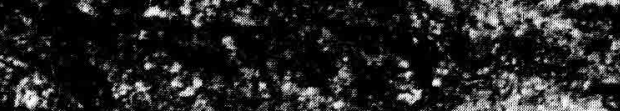

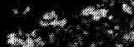

$13+2+2$

Q 30 to

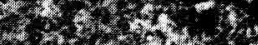

(i)

요

r.

2. $3 x$

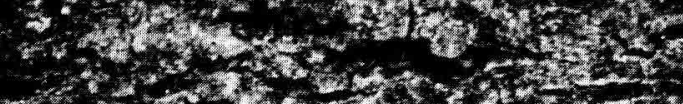

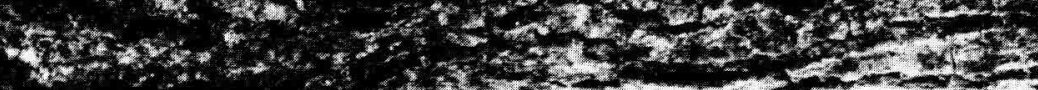

x-

$20 \div 392=$

ơ

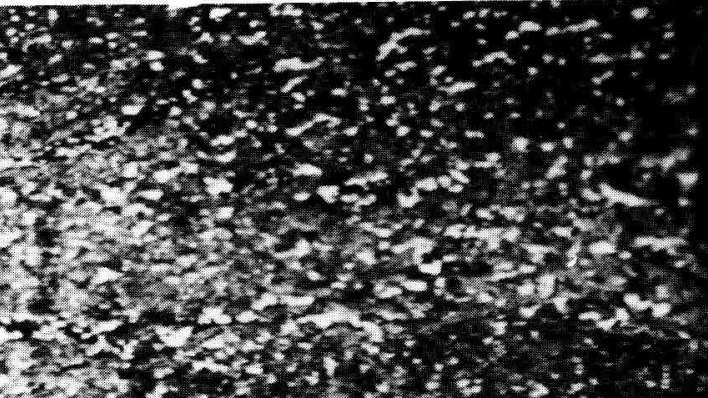

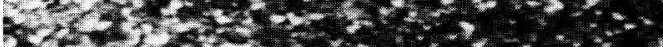

홍

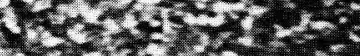

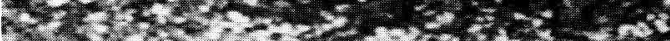

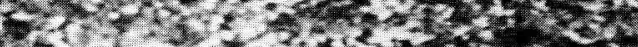

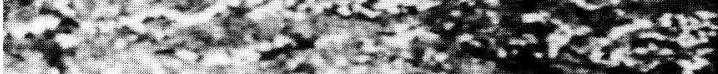


always produce visible symptoms (Rogers and Beakbane, 1957) and it may sometimes be detected only by histological examination or subsequent decline and death of the trees (Sweet and Thulin, 1973). Death may occur after one or two years but in some interspecific grafts of walnuts, trees did not start to decline until they were about 40 years old (Garavel, 1954). In the present experiments the trees had survived for 8-22 years without evidence of decline.

The rootstock used in grafting is unlikely to have produced the systematic differences observed between clones in abundance of $C$. fagisuga. Although the kind of rootstock used in grafting may affect resistance of the scion to disease as in the case of collar rot of apple (Sewell and Wilson, 1973), in the present experiments nonclonal rootstocks were used, the scions being grafted onto genetically heterogeneous rootstocks.

There is thus strong circumstantial evidence that the differences between the clones in infestation by $C$. fagisuga were genetic in origin. The history of attack on clones in the orchards is unknown so we have no information un possible changes in infestation level with time. Observations on an isolated attacked stock at the Forestry Commission Research Station have shown a decline from a very heavy infestation in 1974 (Plate 1a) to a very light infestation in 1978 (Plate 1b). Under natural conditions the apparent recovery of trees from attack by $C$. fagisuga has also been observed (Reichling, 1920 ; Eckstein, 1920 ; Ehrlich, 1934 ; Brower, 1949) and is probably related to structural changes in the bark which are induced by the insect attack (Braun, 1976). This suggests that the degree of infestation of trees may result from a complex relationship between the host resistance to attack and its response to that attack and in addition environmental factors probably also play a part in producing the complex pattern of attack so commonly seen in the forest.

Reçu pour publication en décembre 1979.

\section{Acknowledgments}

Our thanks to Mr I. J. M. Dawson of the Genetics Department for providing us with information on the seed orchards. Thanks also to $\mathrm{Mr} \mathrm{J}$. W. Rusbridge for assistance with data collection and to $\mathrm{Mr}$ I. White of the Statistics Department. We are grateful to Dr D. Lonsdale for valuable discussion and criticism of the manuscript.

\section{Résumé}

Variation de la sensibilité du hêtre (Fagus sp.) à la cochenille

La variabilité dans la sévérité des attaques de la cochenille du hêtre Cryptococcus fogisuga est souvent rapportée dans la littérature. Ce phénomène esł discuté en liaison avec la dispersion de l'insecte et la possibilité de variations de sensibilité des arbres aux ałtaques de $C$. fagisuga. Dans le sud de l'Angleterre, un verger de hêtres greffés par clones révèle des différences dans la sévérité de l'attaque. Les résultats indiquent une origine génétique où résultent des changements physiologiques dûs à une incompatibilité entre greffon et porte-greffe. 


\section{Zusammenfassung}

\section{Unterschiede in der Anfälligkeit der Buche (Fagus sp.) gegenüber der Buchenwollschildlaus (Cryptococcus fagisuga).}

Uber Schwankungen in der Befallsstärke durch die Buchenwollschildlaus im Wald ist in der Literatur häufig berichtet worden. Sie werden im Zusammenhang mit der Ausbreitung der Laus und möglichen Unterschieden in der Anfälligkeit gegenüber Lausbefall zwischen Individuen diskutiert. Verklonte Buchen in Samenplantagen Südenglands zeigten Unterschiede in der Befallsintensität. Die Ergebnisse weisen darauf hin, dass die Unterschiede genetisch bedingt sind oder auf physiologische Veränderungen im Pfropfreis als Folge von Unverträglichkeif mif der Unterlage zurückgehen.

\section{References}

ARGLES G. K., 1937. A review of the literature on stock-scion incompatibility in fruit trees with particular reference to pome and stone fruits. Tech. Commun. Imp. Bur. Fruit Prod., 9.

BARTER G. W., 1947. The beech scale. Forest Insect Investigations, Bi-monthly Progress Report. Science service, Dept. Agric. Ottawa, 3 (4), 1.

BOODLE L. A. and DALLIMORE W., 1911. Report on investigations made regarding « Beech Coccus " (Cryptococcus fagi Barensprung). Roy. Bot. Gard., Kew Bull. Misc. Inform., 332-343.

BRAUN H. J., 1976. Das Rindensterben der Buche, Fagus sylvatica L., verursacht durch die Buchenwollschildlaus Cryptococcus fagi Bär II Ablauf der Krankheit. Eur. J. For. Path., 7, 76-93.

BROWER A. E., 1949. The beech scale and beech bark disease in Acadia National Park. J. econ. Ent., 42 (2), 226-8.

CAMP W. H., 1950. A biogeographic and paragenetic analysis of the American beech (Fogus) : Academy of Natural Sciences of Philadelphia. Am. Philos. Soc. Ybk., 166-169.

CAMP W. H., 1951. A study of relative virulence of beech bark disease on the several types of forest beech present in eastern Canada and Maine. Academy of Natural Sciences of Philadelphia. Am. Philos. Soc. Ybk., 180-183.

CARPENTER G. H., 1903. Woolly scales of the beech. Cryptococcus fogi Bärensp. [In] Injurious insects and other animals observed in Ireland during the year 1902. Roy. Dublin Soc. Econ. Proc., 1 : 207.

DICKSON A. G. and SAMUELS E. W., 1956. The mechanism of controlled growth of dwarf apple trees. J. Arnold Arboret., 37, 307-313.

ECKSTEIN, 1920. Wieder die Buchen-Wollschildlaus, Cryptococcus fagi. Deut. Forst-Ztg., 35, $194-195$.

EHRLICH J., 1934. The beech bark disease. A Nectria disease of Fagus following Cryptococcus fagi (Baer.) Can. J. Res. 10, Spec No. 593-692.

FORESTRY COMMISSION, 1926. The felted beech coccus (Cryplococcus fagi Baerensp.). Leaflet, 15, 1-4.

GARAVEL L., 1954. Enquête sur le comportement du noyer noir d'Amérique en tant que postegreffe de variétés de noyers indigènes. Rev. forest française No. 4, 217-224.

GILLANDERS A. T., 1908. Cryptococcus fagi (Baerensprung). [In] Forest Entomology. Blackwood, Edinburgh and London, pp. 234-238.

GIERTYCH M., 1975. Seed orchard designs. [In] Seed orchards, Ed. R. Faulkner. Forestry Commission Bulletin, 54, H. M. S. O., 25-37.

GREEN E. E., 1915. Cryptococcus fagi Baerensp. [In] Observations on British Coccidae in 1914, with descriptions of new species. Ent. Mon. Mag., 51, 180-181.

KUTHE K. and KRÄMER K., 1961. Zur Bekämpfung der Buchenwollschildlaus (Cryptococcus fagi Bär) mit chemischen mitteln. Anzeiger für Schödlingskunde, 34, 42-43.

LOHMAN M. L. and WATSON A. J., 1943. Identity and host relations of Nectria spp. associated with diseases of hardwoods in the eastern states. Lloydia, 6 (2), 77-108.

LONSDALE D., 1980. Nectria infection of beech bark in relation to infestation by Cryptococcus fagisuga Lind. Eur. J. For. Path., 10, 161-168.

NEWSTEAD R., 1901. Monograph of the coccidae of the British Isles. 1 Ann. vol. of Ray. Soc. (1900) PP. 1, 4, 28-29, 41.

PARKER E. J., 1974. Beech bark disease Ph. D. Thesis Univ. Surrey.

REICHLING, 1920. Die Buchenwollaus, Cryptococcus fagi Bäpenspr. In Westfalen sowie über ihre Bekämpfung Jahresber Westfal. Provinzialer Wiss, Kunst. (Muenster), 47-48, 15-17. 
ROGERS W. S. and BEAKBANE A. B., 1957. Stock and Scion relations. A. Rev. Pl. Physiol., 8, 217-236. SCHENK P. J., 1924. De Beukenwolluis. Floralio, 45, 508.

SEWELL G. W. F. and WILSON J. F., 1973. Phytophthora collar rot of apple : influence of the rootstock on scion variety resistance. Ann. appl. Biol., 74, 159-169.

SHIGO A. L., 1964. Organism interactions in the beech bark disease. Phyfopathology, 54 (3), $263-269$.

SIEGEL. S., 1956. Nonparametric statistics for the behavioural sciences. 312 pp. McGraw-Hill. N. Y. Toro. Lond.

SWEET G. B. and THULIN I. J., 1973. Graft incompatibility in radiata pine in New Zealand. N. Z. Jl. For. Sci., 3 (1), 82-90.

THOMSEN M., BUCHWALD N. F, and HAUBERG P., 1949. Attack of Cryptococcus fagi, Nectria galligena and other parasites on beech in Denmark 1931-1943. Def forstlige Forsagsvaesen, 18, 97-326.

WAINHOUSE D. Dispersal of first instar larvae of the felted beech scale Cryptococcus fagisuga. J. appl. Ecol. (in press). 